\title{
Meningeal Tuberculosis Presented As A Myasthenia Gravis Picture
}

\section{Raziel Castillo-Guevara, Adriana Martínez-Mayorga and Ildefonso Rodriguez-Leyva*}

Hospital Central "Dr. Ignacio Morones Prieto", Medicine Faculty, Universidad

Autonoma de San Luis Potosí, Mexico

*Corresponding Author: Ildefonso Rodriguez-Leyva, Hospital Central “Dr. Ignacio

Morones Prieto", Medicine Faculty, Universidad Autonoma de San Luis Potosí,

Mexico.

DOI: $10.31080 /$ ASMI.2020.03.0647
Received: June 15, 2020

Published: July 10, 2020

(C) All rights are reserved by Ildefonso

Rodriguez-Leyva., et al.

\begin{abstract}
Objective: To share an uncommon clinical case presentation of a young adult who shows a clinical picture of myasthenia gravis and had neuroinfection problem.

Presentation of the Case: A 20-year-old woman with progressive and fluctuant ptosis and diplopia was evaluated through clinical and extension studies (including a repetitive neurostimulation test), but the outcome and, finally, the CSF study help us to make the diagnosis of tuberculosis from the CNS.

Results: The high opening pressure, with the xanthochromic aspect and the hypoglycorrhachia with pleocytosis with mononuclear cell elevation and Tb-positive PCR, make us the guidelines for the diagnosis and final treatment. Magnetic resonance imaging shows a pinealoma and a lightly bright of the arachnoid structures.

Conclusion: The multiple forms of presentation of this endemic disease push us to consider this unfortunate problem in patients with cranial nerve affection due to arachnoiditis secondary to CNS tuberculosis.
\end{abstract}

Keywords: Tuberculosis; Pulmonary; Vascular; Parenchymatous; Spinal

\section{Introduction}

Tuberculosis (TB) is produced by bacteria (Mycobacterium tuberculosis), an obligate aerobe, a facultative intracellular bacterium that most often affects the lungs. TB is blowout through the air when people with pulmonary TB cough, sneeze or spit. A susceptible person needs to inhale only a few bacilli to become infected, while the most common manifestation of tuberculosis is pulmonary, extrapulmonary central nervous system tuberculosis is harder to diagnose and inherently has a worse outcome than pulmonary tuberculosis, especially if treatment is delayed. Multiple factors are related; old age, female sex, alcoholism and abuse of substance, immigration, poor educational level, and is until now a social stigma $[1,2]$.
According to the WHO, about one-quarter of the world's population is estimated to be infected by tuberculosis bacteria, 10 million people fall ill with tuberculosis every year, 1.5 million people die from tuberculosis each year making it the world's top infectious killer, in Mexico, there were 139,181 new tuberculosis cases from 2010 to 2016 of which 373 were CNS TB $[3,4]$.

Furthermore, tuberculosis is the leading cause of death in people with HIV coinfection and a significant contributor to antimicrobial resistance.

Central nervous system tuberculosis (CNS TB) is one of the most devastating clinical manifestations of tuberculosis and is associated with high mortality. It occurs in 1-5\% of all patients with tuberculosis and $10 \%$ of those with HIV infection. 
Bangladesh, China, India, Indonesia, Nigeria, Pakistan, Philippines, and South Africa are the eight countries where about half of all people with tuberculosis can be found. These are also low- and middle- income countries like Mexico [1].

Risk factors for acquiring pulmonary tuberculosis include human immunodeficiency virus (HIV) infection, diabetes mellitus, chronic use of corticosteroids, chronic renal failure, malnutrition, injection drug use, silicosis, solid organ transplantation, and carcinoma of the head and neck [5].

Higher risk of CNS TB is described in children younger than five years and patients under immunosuppression, such as HIVpositive patients or under treatment with corticosteroids or tumor necrosis factor-alpha (TNF-alpha) blockage, malnutrition, alcoholism, concomitant malignancy, recent measles, and measles in childhood [6-9].

Generally, CNS TB occurs most often as a complication of pulmonary TB; imaging of the lungs may demonstrate latent infection. Moreover, an individual treated for pulmonary TB years or even decades previously can manifest CNS TB [10].

We present a case report of an uncommon manifestation of CNS TB that mimics a myasthenic syndrome and other characteristic features of tuberculous meningitis.

\section{Case Report}

We share the clinical case of a 20 years old woman who presented to the ER with a three months history before admission characterized by anxiety, tension-type headache, nausea and vomiting, two months before admission the patient notes fluctuating ptosis, first of the left eye that is worst in the afternoon and diplopia that is awful in the afternoon as well. She is diagnosed by a facultative like myasthenia gravis and prescribes pyridostigmine $30 \mathrm{mg}$ every 4 hours; two weeks later, she experiences an anxiety crisis and left hemiparesis, progressive worsening of the headache attacks and diplopia.

At the time of examination, we found an anxious and apprehensive patient, cognition and language was normal.
Examination of the cranial nerves revealed two-sided papilledema, visual acuity 20/40 in both eyes, bilateral ptosis that predominates on the left eye, and left abducens palsy.

The proximal weakness of the upper extremities $(4+/ 5)$.

The rest of the examination was unremarkable.

The CSF analysis showed elevated proteins and low glucose with a CSF glucose/serum glucose ratio of 0.13 , elevated white cells with a mononuclear predominance (Table 1), the patient is HIV negative and has no other risk factors immunosuppression.

\begin{tabular}{|l|c|}
\hline & Admission \\
\hline Glucose & $75.7 \mathrm{mg} / \mathrm{dl}$ \\
\hline Urea & $22.26 \mathrm{mg} / \mathrm{dl}$ \\
\hline Creatinine & $0.63 \mathrm{mg} / \mathrm{dl}$ \\
\hline BUN & $10.4 \mathrm{mg} / \mathrm{dl}$ \\
\hline WBC & $8.03 \mathrm{~K} / \mathrm{uL}$ \\
\hline RBC & $4.85 \mathrm{M} / \mathrm{uL}$ \\
\hline Hematocrit & $42.9 \%$ \\
\hline Platelets & $270 \mathrm{~K} / \mathrm{uL}$ \\
\hline Hemoglobin & $14.4 \mathrm{~g} / \mathrm{dl}$ \\
\hline Na & $131 \mathrm{mmol} / \mathrm{L}$ \\
\hline K & $3.7 \mathrm{mmol} / \mathrm{L}$ \\
\hline Cl & $104 \mathrm{mmol} / \mathrm{L}$ \\
\hline C Reactive Protein & $0.2 \mathrm{mg} / \mathrm{dl}$ \\
\hline Total serum protein & $6.76 \mathrm{gr} / \mathrm{dl}$ \\
\hline Albumin & $4.24 \mathrm{gr} / \mathrm{dl}$ \\
\hline Globulin & $2.42 \mathrm{gr} / \mathrm{dl}$ \\
\hline AST & $14.4 \mathrm{U} / \mathrm{L}$ \\
\hline ALT & $12.8 \mathrm{U} / \mathrm{L}$ \\
\hline Direct bilirubin & $0.2 \mathrm{mg} / \mathrm{dl}$ \\
\hline Indirect bilirubin & $0.27 \mathrm{mg} / \mathrm{dl}$ \\
\hline CSF & Xantochromic \\
Proteins & $453.2 \mathrm{mg} / \mathrm{dl}$ \\
Cells & $259 / \mathrm{mm}{ }^{3}$ \\
WBC & $250 / \mathrm{mm}{ }^{3}$ \\
RBC & $9 / \mathrm{mm}{ }^{3}$ \\
Differential & Nononuclear $80 \%$ \\
\hline Glucose & Nolymorphonuclear $20 \%$ \\
\hline Andian Ink Test & $10 \mathrm{mg} / \mathrm{dl}$ \\
\hline
\end{tabular}

Table 1: Laboratory results. 
The chest X-ray was normal (Figure 1).

The MRI shows a $13.6 \mathrm{~mm}$ diameter pinealoma and increases of bright (lightly) of the arachnoid structures (Figure 2).

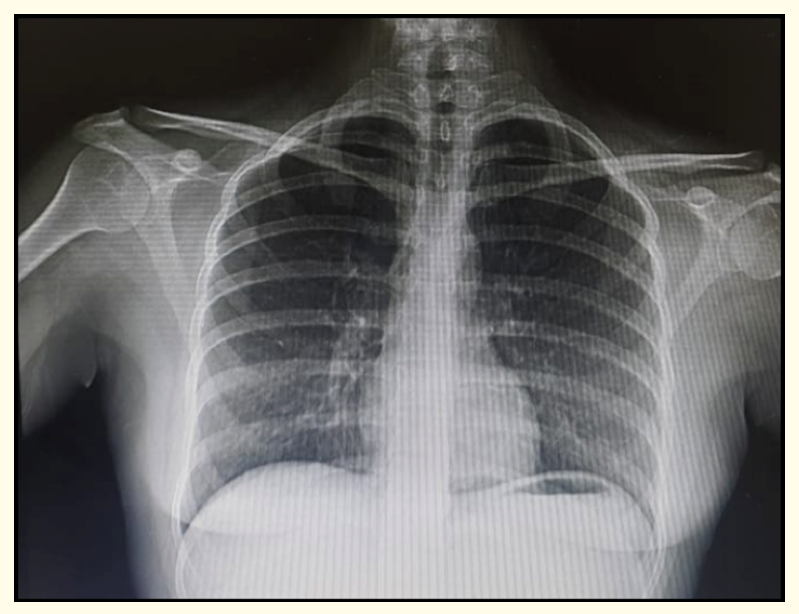

Figure 1: Normal chest X-ray.

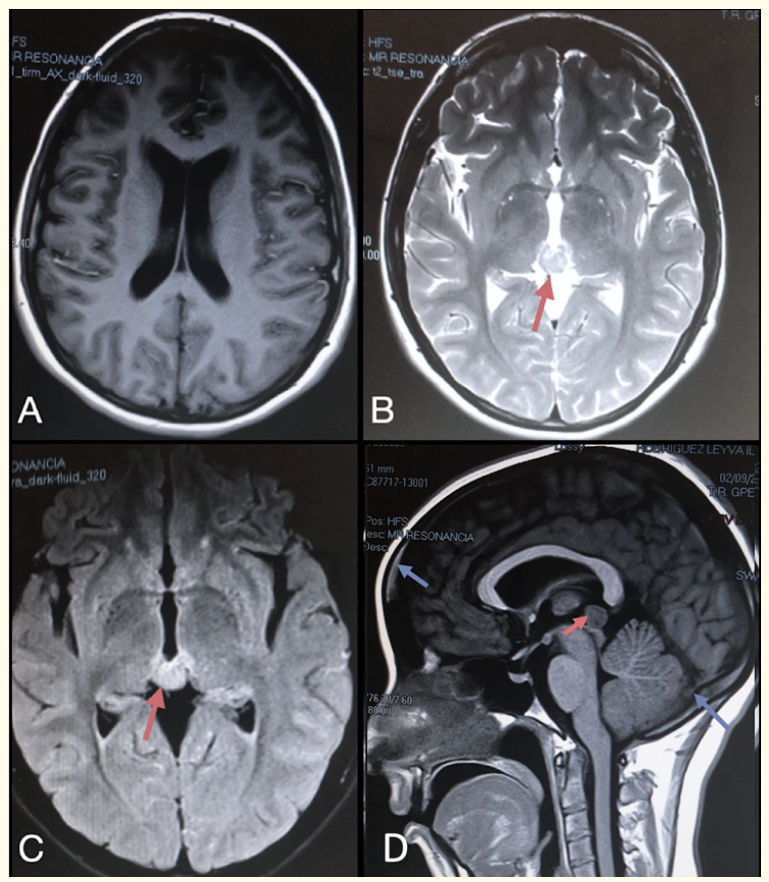

Figure 2: Typical axial T1-weighted magnetic resonance image

(A), axial T2-weighted and axial fluid-attenuated inversion recovery (FLAIR) magnetic resonance image that demonstrates the pinealoma (red arrow) (B, C), sagittal T1-weighted magnetic resonance image is showing increases of bright of arachnoid structures (blue arrows) (D).

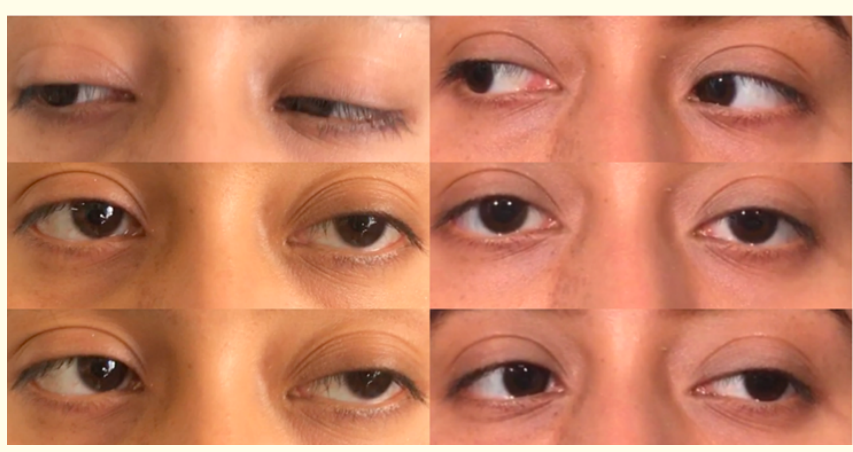

Figure 3: On the left, it is possible to see the ocular movements before starting the anti-tuberculosis treatment and on the right after three months of treatment with a definite improvement of the patient's ocular movements.

\section{Differential diagnosis}

Our provisional diagnosis includes chronic meningitis with intracranial hypertension that explains the headache, nausea, vomiting, papilledema and the multiple cranial neuropathies, and myasthenic syndrome based on the typical fluctuating presentation, the differential diagnosis is broad, the possible causes of chronic meningitis are included in table 2, on the other hand, myasthenic syndrome (myasthenia gravis vs. Lambert Eaton myasthenic syndrome [LEMS]) was considered by the presence of fluctuating ptosis and diplopia that worsens in the afternoon, and the proximal weakness in upper extremities found on examination, the differential diagnosis of myasthenia gravis and LEMS is based on the ocular or generalized involvement and is shown in table 3.

\section{Discussion}

According to the history, examination, and extension studies, we were able to discard a myasthenic syndrome as a cause of the patient's symptoms; this is an important issue because we described an uncommon presentation of CNS TB.

According with the study of Christie., et al. [11] the presence of leukocytes around 201 (42-2,8459, protein mg/dL of 174 (66 357) and glucose mg/dL 35 (9 - 132) could support the diagnosis of CNS TB, our patient had in the CSF 259 of leukocytes, $453 \mathrm{mg} /$ $\mathrm{dL}$ and $10 \mathrm{mg} / \mathrm{dL}$ of glucose (mononuclear leukocytosis, hypoglucorrachia, elevated level of proteins in CSF) highly compatible with tuberculosis, then we decided start with antifimic treatment. 


\section{Infection}

- $\quad$ Acute pyogenic meningitis

- Mycobacterium species

- $\quad$ Syphilis

- $\quad$ Lyme disease

- Viral meningitis (human T-cell lymphotropic virus type 1 [HTLV-1], herpesviruses)

- $\quad$ Fungal meningitis (cryptococcal meninigitis, coccidioidal meningitis)

- $\quad$ Primary amebic meningitis

Autoimmune/Inflammatory

- $\quad$ Sarcoidosis

- $\quad$ Rheumatoid arthritis

- Sjögren syndrome

- Granulomatosis with polyangiitis

- Vogt-Koyanagi-Harada syndrome and other uveomeningitis syndromes

- IgG4-related pachymeningitis

- Histiocytosis

Neoplasm

- $\quad$ Metastatic disease (breast, lung, melanoma)

Iatrogenic

- Lumbar puncture

- $\quad$ Shunt placement

- Craniotomy

- Intrathecal chemotherapy

other

- Spontaneous intracranial hypotension

- Venous sinus thrombosis

- Extramedullary hematopoiesis

- Post-subarachnoid hemorrhage

- Idiopathic

Table 2: Differential diagnosis of chronic meningitis.

There were no clues on history, examination, or extension studies that make us think about autoimmune/inflammatory, neoplasm, or iatrogenic causes, in the patient.

There are several forms of presentation of CNS TB.

Tuberculous meningitis is the most common manifestation of CNS TB, and it occurs most frequently in young people. At least

\begin{tabular}{|c|c|c|}
\hline Anatomic & Ocular Myasthenia Gravis & $\begin{array}{c}\text { Generalized Myasthe- } \\
\text { nia Gravis }\end{array}$ \\
\hline Ophthalmic & $\begin{array}{c}\text { Thyroid eye disease, leva- } \\
\text { tor dehiscence }\end{array}$ & - \\
\hline $\begin{array}{l}\text { Central ner- } \\
\text { vous system }\end{array}$ & $\begin{array}{c}\text { Blepharospasm, brainstem } \\
\text { lesion }\end{array}$ & $\begin{array}{c}\text { Amyotrophic lateral } \\
\text { sclerosis, Parkinson } \\
\text { disease/parkinsonism }\end{array}$ \\
\hline $\begin{array}{l}\text { Peripheral ner- } \\
\text { vous system } \\
\text { Nerve }\end{array}$ & $\begin{array}{c}\text { Microvascular/diabetic } \\
\text { cranial neuropathies, } \\
\text { Horner syndrome, Miller } \\
\text { Fisher syndrome, isolat- } \\
\text { ed/combined III, IV, and VI } \\
\text { cranial neuropathies }\end{array}$ & $\begin{array}{l}\text { Amyotrophic lateral } \\
\text { sclerosis, Guillain-Barré } \\
\text { syndrome, focal } \\
\text { neuropathies affecting } \\
\text { craniobulbar function }\end{array}$ \\
\hline $\begin{array}{l}\text { Neuromuscu- } \\
\text { lar junction }\end{array}$ & $\begin{array}{c}\text { Lambert-Eaton myasthen- } \\
\text { ic syndrome, botulism, } \\
\text { congenital myasthenic } \\
\text { syndrome }\end{array}$ & $\begin{array}{c}\text { Lambert-Eaton my- } \\
\text { asthenic syndrome, } \\
\text { botulism, congenital } \\
\text { myasthenic syndrome, } \\
\text { organophosphate } \\
\text { toxicity }\end{array}$ \\
\hline Muscle & $\begin{array}{c}\text { Chronic progressive } \\
\text { external ophthalmoplegia, } \\
\text { oculopharyngeal muscu- } \\
\text { lar dystrophy, myotonic } \\
\text { dystrophy }\end{array}$ & $\begin{array}{l}\text { Chronic progressive } \\
\text { external ophthalmople- } \\
\text { gia, other mitochondri- } \\
\text { al myopathies, oculo- } \\
\text { pharyngeal muscular } \\
\text { dystrophy }\end{array}$ \\
\hline Other & $\begin{array}{c}\text { Idiopathic, convergence } \\
\text { spasm }\end{array}$ & $\begin{array}{c}\text { Systemic disease, } \\
\text { thyroid disease, idio- } \\
\text { pathic, chronic fatigue, } \\
\text { functional/conversion } \\
\text { disorder }\end{array}$ \\
\hline
\end{tabular}

Table 3: Differential diagnosis for Myasthenia Gravis.

$75 \%$ of patients have active pulmonary TB at presentation and occurs most often within three months of primary infection [2]; dissemination of TB involves seeding to other sites, including the CNS, various mechanisms by which the bacilli migrate into the lymphatic system or bloodstream have been suggested. Infection in the subarachnoid space can start by these mechanisms or also by extension from a caseating focus in the adjacent cortex $[9,12]$. The patient had no evidence of active tuberculosis on lungs at the moment of diagnosis of CNS TB. The neurologic manifestations of tuberculous meningitis can develop insidiously or in an abrupt manner similar to bacterial or viral meningitis, and that is why these entities should be suspected as a differential diagnosis.

The most common manifestations include fever, vomiting, and apathy. Clinical cranial neuropathy is frequent given the involvement of the basal meninges and cisterna ambiens. It is seen in 
$17.4 \%$ to $40 \%$ and is caused by vascular compromise resulting in ischemia of the nerve or caused by entrapment of the nerves by the exudates [6], cranial nerves II (optic), VI (abducens) and VII (facial) are the most often affected [10], on this case the left abducens and the III cranial nerve were affected.

On neuroimaging, a characteristic triad of findings includes basal meningeal enhancement, hydrocephalus which is a complication when CSF protein is more significant than $500 \mathrm{mg} / \mathrm{dl}$, and infarctions in the supratentorial brain parenchyma and brainstem [2], on the patient's MRI there is no evidence of any of these complications, but we found a pinealoma as incidental finding.

Tuberculoma is present in $10 \%$ of patients with tuberculous meningitis, the clinical presentation changes according to the location of the lesion but includes headache, seizures, focal neurologic deficits and papilledema, all of these signs and symptoms except seizures were present in our patient however the MRI did not demonstrate this type of lesions.

A tuberculous abscess occurs in less than $10 \%$ and is a later stage of tuberculoma, and the clinical symptoms are similar; differentiation is given by neuroimaging and neuropathology, although it can be difficult sometimes to make the difference.

The clinical presentation of CNS TB is depended of the localization of the infection, arachnoid, subependymal, vascular, parenchymatous, spinal, vertebral localization. It is frequent to find nerve cranial affection, however the presentation as a myasthenic syndrome is in our knowledge not reported previously. However, there are so uncommon presentations as a motor neuron disease $[13,14]$.

There is no complete explanation for the myasthenic syndrome features seen in our patient, we think is secondary to arachnoid affection, but with the treatment, these manifestations disappeared.

\section{Conclusion}

Tuberculosis is a global health problem. In Mexico, we are affected in an endemic way by these bacteria. The clinical presentation is variable, and the differential diagnosis includes a great variety of diseases, we share a clinical case report of a patient with tuberculous meningitis that presented with features of the myasthenic syndrome, this presentation is uncommon, and this gives light to the knowledge that tuberculosis is the great imitator and that in endemic countries always should be suspected.

\section{Bibliography}

1. Storla., et al. "A systematic review of delay in the diagnosis and treatment of tuberculosis". BMC Public Health 8.1 (2008): 15.

2. Zunt, Joseph R. "Tuberculosis of the central nervous system". CONTINUUM: Lifelong Learning in Neurology 24.5 (2018): $1422-1438$

3. Taghizade Moghaddam., et al. "Tuberculosis: past, present and future". International Journal of Pediatrics 4.1 (2016): 12431254.

4. Bello-López., et al. "Morbidity trends and risk of tuberculosis: Mexico 2007-2017". Canadian Respiratory Journal 2019 (2019).

5. Cherian A and SV Thomas. "Central nervous system tuberculosis". African Health Sciences 11.1 (2011).

6. Gupta Rakesh K and Sunil Kumar. "Central nervous system tuberculosis”. Neuroimaging Clinics 21.4 (2011): 795-814.

7. Yaramiş Ahmet., et al. "Central nervous system tuberculosis in children: a review of 214 cases". Pediatrics 102.5 (1998): e49e49.

8. Schaller Martin Alexander., et al. "Central Nervous System Tuberculosis". Clinical neuroradiology 29.1 (2019): 3-18.

9. Donald PR., et al. "Tuberculous meningitis and miliary tuberculosis: the Rich focus revisited". Journal of Infection 50.3 (2005): 193-195.

10. Sharma Pawan., et al. "Incidence, predictors and prognostic value of cranial nerve involvement in patients with tuberculous meningitis: a retrospective evaluation". European Journal of Internal Medicine 22.3 (2011): 289-295.

11. Christie Laura J., et al. "Diagnostic challenges of central nervous system tuberculosis". Emerging Infectious Diseases 14.9 (2008): 1473.

12. Davis Angharad Grace., et al. "The pathogenesis of tuberculous meningitis". Journal of Leukocyte Biology 105.2 (2019): 267280. 
13. Cherian A and SV Thomas. "Central nervous system tuberculosis". African Health Sciences 11.1 (2011).

14. Ren Jie., et al. "A rare case of tuberculosis with motor neuron disease". World Journal of Surgical Oncology 12.1 (2014): 381.

\section{Assets from publication with us}

- Prompt Acknowledgement after receiving the article

- Thorough Double blinded peer review

- Rapid Publication

- Issue of Publication Certificate

- High visibility of your Published work

Website: www.actascientific.com/

Submit Article: www.actascientific.com/submission.php

Email us: editor@actascientific.com

Contact us: +919182824667 